\title{
STANOVENÍ VYBRANÝCH EKOSYSTÉMOVÝCH FUNKCÍ Z DAT DRUŽICE SENTINEL-2
}

\author{
Pavel VYVLEČKA ${ }^{1}$ \\ ${ }^{1}$ Katedra geoinformatiky, Př́rodovědecká fakulta, Univerzita Palackého, 17. listopadu 50, 771 46, Olomouc, \\ Česká republika \\ pavel.vyvlecka01@upol.cz
}

doi: https://doi.org/10.31490/9788024845081-118

\begin{abstract}
Abstrakt
Práce se zabývá nalezením vhodných algoritmů pro zpracování družicových dat Sentinel-2, které budou platné pro dané zájmové území. Výsledky algoritmů slouží jako kvantifikátory při konečné kvantifikaci ekosystémových funkcí. Algoritmy jsou zaměřeny na množství a strukturu biomasy, zásoby uhlíku $v$ nadzemní biomase, vlhkost aktivního povrchu, vlhkost půdy, ochranu půdy před vodní erozí a podíl fotosynteticky aktivní složky vegetace. Testování algoritmů probíhá na zájmovém území povodí reky Dřevnice. Družicové snímky byly staženy pro každý měsíc v časovém období od března 2018 do prosince 2018. Při zpracování družicových dat bylo použito obecných metod využívajících se v oblasti DPZ. Výsledné hodnoty biomasy a uhlíku jsou konfrontovány s výsledkem pozemního měření výzkumné stanice Bílý Křiž a dále $s$ průměrnými hodnotami uhlíku ve vybraných biotopech zájmového území. Práce je zaměřena ke zjištění, zdali družicová data Sentinel-2 jsou vhodná k dané tematice stanovení ekosystémových funkcí.
\end{abstract}

\section{Abstract}

The main aim of the thesis is to find suitable algorithms for processing remote sensing data of Sentinel-2 satellite, which will be valid for the area of interest. The results of the algorithms are used as indicators for the final quantification of ecosystem functions. The algorithms are focused on the estimation and structure of biomass, carbon estimation in above-ground biomass, moisture of active surface, soil moisture, soil protection against water erosion and proportion of photosynthetically active part of the vegetation. Algorithms are tested in the area of interest in a basin of river Dřevnice. Satellite images were downloaded for each month in the period from March 2018 to December 2018. In data processing were used general methods which are used in remote sensing. The values of biomass and carbon estimation are confronted with the results of ground measurements from research station Bílý Kř́ž and from average values of carbon in selected biotopes. The thesis is focused on finding out if the satellite data from Sentinel-2 are suitable for determining ecosystem functions.

Klíčová slova: Dálkový průzkum Země; Sentinel-2; ekosystémové funkce; biomasa a uhlík

Keywords: Remote sensing; Sentinel-2; ekosystém function; biomass and carbon

\section{ÚVOD}

Správné fungování ekosystémů je nedílnou součástí udržení přírody $v$ rovnováze. Mezi ekosystémy probíhají interakce, které jsou zásahem člověka narušeny, či změněny. Zmíněnými interakcemi mezi ekosystémy jsou ekosystémové funkce. Následek změny ekosystémových funkcí má dopad na každodenní život. Typickým příkladem je odlesňování a vznik zemědělsky využívané půdy. De Groot a kol. (2002) rozdělil ekosystémové funkce do čtyř základních kategorií a vymezil 23 ekosystémových funkcí.

K odhalení změn uvnitř ekosystémů může sloužit monitoring. $V$ případě monitoringu rozsáhlejších území za časově se opakující období je nejvhodnějším způsobem dálkový průzkum Země (DPZ). Díky svým vlastnostem jsou družicová data efektivním způsobem pro monitoring velkých nebo odlehlých míst, kde by bylo obtížné provádět pozemní měření. $V$ konfrontaci s metodami destruktivními tak Ize jednoduše, efektivně a rychle získat přehled o změně v krajině na větším území. Díky způsobům získáním dat o biomase, uhlíku, struktuře biomasy či vlhkostních poměrech, je možné kvantifikovat různé ekosystémové funkce, které jsou 
závislé na daných proměnných. Například výpočet biomasy a uhlíku může sloužit k určení ekosystémové funkce skladování a sekvestrace uhlíku, výpočet C-faktoru jako ekosystémová funkce k zabránění vodní nebo kapkové eroze. Ve studii Pettorelli a kol. (2018) je sestaven seznam volně dostupných globálních družicových dat, které mají potenciál pro monitoring či určení ekosystémových funkcí. Sentinel-2 je podle studie vhodný pro určení NDVI, LAI, FAPAR či Land Cover.

\section{DATA A METODY}

Zájmovým územím je povodí Dřevnice. Povodí se nachází ve Zlínském kraji a jeho plocha činí 436,52 km² (ČHMÚ, 2018). Řeka pramenní v oblasti Hostýnských vrchů poblíž obce Držková. Její ústí se nachází u Otrokovic, kde se vlévá do Moravy. Ve zkoumané oblasti se nacházejí oblasti lesních pozemků, luk, zemědělské oblasti, ale také konurbace Zlín - Otrokovice.

V práci byla použita volně dostupná data z programu Copernicus. Snímky z družic Sentinel-2 jsou multispektrální o rozlišení 10,20 a 60 metrů. Celkově každý snímek obsahuje 13 spektrálních pásem. Hlavní výhodou snímků družic Sentinel-2 je perioda snímání (10 dnů pro jednu družici, 5 dnů pro dvě družice v oblasti rovníku), dostupnost dat a použitelnost spektrálních pásem. Snímky byly staženy za časové období od března 2018 do prosince 2018. Na zpracování snímků bylo použito obecných metod využívajících se v oblasti DPZ, jako je mozaikování (mosaicing), prostorový ořez (spatial subset), extrakce spektrálních pásem (spectral band extraction), kombinace pásem (band math), ořez podle masky (extract by mask) a převzorkování (resampling). $\vee$ testovací a analytické části je kladen důraz na metody určování vegetačních indexů z družicových snímků.

\section{TESTOVACÍ ČÁST}

\section{Biomasa a Uhlík}

Obecně biomasa se skládá z nadzemní biomasy (above-ground biomass) a podzemní biomasy (bellowground living biomass). Do nadzemní biomasy Ize zařadit stromy nebo keře. Do podzemní biomasy patří kořeny a odumřelá biomasa nacházející se $v$ půdě. Biomasa je často definována při suché hmotnosti a udává se jako podíl hmotnosti $\mathrm{k}$ jednotce plochy $\left(\mathrm{kg}^{*} \mathrm{~m}^{-2}\right)$ (Liang a kol., 2012). Zásobu uhlíku Ize zjistit jednoduchým přepočtem dle koeficientu 0,5. Koeficient je průměrem dle ÚHUL (2018), kde platí koeficienty 0,51 pro jehličnaté lesy a 0,49 pro listnaté lesy. Pro výpočet bylo použito celkem 5 algoritmů, které jsou popsány $v$ diplomové práci Vyvlečka (2020). Kromě toho byla použita i metoda, která kombinovala data ze Sentinelu-1 a Sentinelu-2, nicméně při testování byla posouzena jako nevhodná pro určení biomasy a uhlíku v daném zájmovém území.

\section{C-faktor}

Vegetační faktor určující strukturu a pokryvnost biomasy. Struktura vegetace dokáže rozložit dobu dopadu deštové kapky na delší dobu, tím zmírní jak erozi pluviální tak i horizontální. Hodnota C-faktoru je nejmenší pro lesní porosty, nicméně ochrana proti erozi je nejvyšší. Největší hodnota C-faktoru je pro holou pưdu, kde je ochrana proti erozi naopak nejmenší. V práci Dragicevic a kol. (2011) byla určena průměrná hodnota Cfaktoru podle tříd Corine Land Cover. Hodnota pro listnaté (311), jehličnaté (312) a smíšené lesy (313) byla určena na 0,004 . Pro louky (231) byla hodnota 0,02 a pro prírodní pastviny (321) to bylo 0,05 . Přechodová stádia lesa a křovin (324) dosahovaly průměrné hodnoty 0,007 . Stejně jako v předchozím prípadě bylo testováno celkem 5 algoritmů.

\section{Fraction of Absorbed Photosynthetically Active Radiation (FAPAR)}

Je podíl fotosynteticky aktivního záření pohlceného vegetací pro aktivitu fotosyntézy. Vztahuje se pouze na zelené a živé části rostlin. FAPAR závisí na struktuře rostliny, optických vlastnostech vegetačního prvku, atmosférických podmínkách a úhlové konfiguraci (Copernicus, 2019). Testovány byly 3 algoritmy založené na vegetačním indexu NDVI a algoritmus Biophysical Processor dostupný v softwaru SNAP. 


\section{VÝSLEDKY}

\section{C-faktor}

Prvním testovaným kvantifikátorem byl C-faktor. Výsledky testovaných algoritmů byly konfrontovány $\mathrm{s}$ referenčními průměrnými hodnoty podle Dragicevic a kol. (2011). Výsledné hodnoty by se měly pohybovat v rozmezí 0 a 1. Nejvhodnějším kandidátem pro dané území je algoritmus ze studie Knijff a kol. (1999), který je nejbližší aproximací referenční hodnoty napříč časovým období a má i největší aproximaci $v$ hlavní vegetační sezóně. Při testování byl algoritmus nejpoužitelnější pro všechny vybrané typy biotopů (Y5, Y6, K3). C-faktor je používán pro určení protierozní funkce.

\section{Biomasa a uhlík}

Dalšími testovanými byly algoritmy pro určení biomasy a uhlíku. Zde byly dostupné dvě odlišné referenční hodnoty. První hodnota byla získána pozemním měěením z výzkumné stanice Bílý Kříž z 11. Listopadu 2018. Hodnota nadzemní biomasy byla určena na 127,38 t.ha $^{-1}$. Bylo nutné najít nejbližší použitelný snímek, kterým byl snímek ze 4. Listopadu 2018. Získání hodnot biomasy z dat Sentinel-2 proběhlo z plochy čtyři hektary. Průměrem byla zjištěna hodnota pro každý algoritmus (Tabulka 1).

Tabulka 1 Přehled získaných hodnot biomasy

\section{Srovnání hodnoty biomasy (t.ha-1 ${ }^{-1}$ pozemního měření a ze snímků Sentinel-2 (Listopad 2018)}

pozemní měření biomasy

127,38

Zheng a kol., 2004

430,78

Goodenough a kol., 2005

190,66

Macedo a kol., 2018 (SR)

412,88

Macedo a kol., 2018 (NDVI)

148,25

Askar a kol., 2018

$-78,43$

Další částí je porovnání s hodnotami uhlíku z biotopů DKV, které jsou brány jako dlouhodobé průměrné hodnoty. Referenční hodnoty uhlíku jsou následující: K3 = 12,89 t.ha ${ }^{-1}$, Y5 = 103,75 t.ha ${ }^{-1}$, Y6 = 2,07 t.ha ${ }^{-1}$. Zde byl nejlepším algoritmem Goodenough a kol. (2005), který společně s algoritmem Macedo a kol. (2018) vykazoval nejvyšší aproximaci v průběhu vegetační sezóny. Nicméně v práci se potvrdilo, že algoritmy jsou vhodné pouze pro určení biomasy a uhlíku pro lesní porosty (Tabulka 5). $V$ daném srovnání již nebyl použit algoritmus Askar a kol. (2018), který vykazoval záporné hodnoty biomasy.

Tabulka 2 Hodnota zásoby uhlíku (t.ha ${ }^{-1}$ ) ve vybraných biotopech v záři 2018

\begin{tabular}{lccccc}
\hline & $\begin{array}{c}\text { Zheng a } \\
\text { kol., 2004 }\end{array}$ & $\begin{array}{c}\text { Goodenough } \\
\text { a kol., 2005 }\end{array}$ & $\begin{array}{c}\text { Macedo a } \\
\text { kol., 2018 } \\
\text { (SR) }\end{array}$ & $\begin{array}{c}\text { Macedo a } \\
\text { kol., 2018 } \\
\text { (NDVI) }\end{array}$ & referenční hodnoty \\
\hline $\begin{array}{l}\text { Y5 (Smíšené } \\
\text { hospodářské lesy) }\end{array}$ & 186,5 & 76,53 & 207,87 & 71,05 & 103,75 \\
$\begin{array}{l}\text { Y6 (hospodářské } \\
\text { louky) }\end{array}$ & 94,73 & 48,78 & 122,98 & 57,03 & 2,07 \\
$\begin{array}{l}\text { K3 (Vysoké } \\
\text { mezofilní a } \\
\text { xerofilní křoviny) }\end{array}$ & 117,53 & 52,55 & 145,1 & 60,44 & 12,89 \\
\hline
\end{tabular}




\section{Fraction of Absorbed Photosynthetically Active Radiation (FAPAR)}

Testování pro určení FAPAR probíhalo na stejných plochách jako předchozí dva kvantifikátory. Hodnoty FAPAR by měly nabývat hodnot od 0 do 1 . Bylo tak posuzován procentuální podíl, kdy se výsledné hodnoty algoritmů nacházejí mimo obor hodnot. $\mathrm{V}$ př́padě algoritmů založených na NDVI se procentuální podíl hodnot, který překročil 1 nebo byl menší než 0 , pohyboval $v$ desítkách procent. $U$ algoritmu z Biophysical Processor to bylo $v$ řádech desetin či setin procent, proto byl použit právě ten.

\section{Další indikátory}

Zbylé indikátory životního prostředí byly vypočteny bez dalšího testování. LAI (Leaf Area Index) byl získán pomocí nástroje Biophysical Processor, který je obsažen v softwaru SNAP. Algoritmus počítá index pomocí neuronové sítě a vstupuje do něj 11 vrstev $z$ dat Sentinel-2. LAl se vztahuje ke klimatizační funkci vegetace, jelikož dokáže indikovat hustotu olistění a tím pádem regulovat teplotu povrchu. Z LAl vychází další regulační funkce a tou je zachycení prachových částic $\mathrm{PM}_{10}$, která byla počítána podle studie Botallico a kol. (2016). Vlhkost vegetace byla počítána pomocí indexu NDMI (Normalized Difference Moisture Index), který se někdy označuje jako NDWI (Gao, 1996). Index dokáže detekovat rostliny trpící vodním stresem a do jisté míry taky retenci vody $v$ krajině. Dalším indikátorem byl Wetness-Biomass, který měl nejprve sloužit $k$ výpočtu solární disipace, bohužel Sentinel-2 nesnímá povrch $v$ termálním pásmu a $z$ tohoto důvodu byl použit index samostatně. Dokáže indikovat zdravou zelenou biomasu bez vodního stresu. Všechny použité indikátory a příslušné funkce jsou zaznamenány v tabulce 3 .

Tabulka 3 vhodné algoritmy k príslušným ekosystémovým funkcím

\begin{tabular}{|c|c|c|}
\hline $\begin{array}{l}\text { EKOSYSTÉMOVÁ } \\
\text { FUNKCE }\end{array}$ & VHODNÝ ALGORITMUS & ZDROJ \\
\hline \multirow{3}{*}{$\begin{array}{l}\text { Produkční funkce } \\
\text { (sekvestrace uhlíku) }\end{array}$} & $N D 45=128 \times \frac{B 8-B 11}{B 8+B 11}+128$ & \\
\hline & Biomasa $\left(\frac{m 3}{h a}\right)=-478,58+4,5041 \times N D 45$ & $\begin{array}{l}\text { Goodenough a } \\
\text { kol., } 2005\end{array}$ \\
\hline & Carbon $=$ Biomasa $\times 600 \times 0,5$ & \\
\hline Protierozní funkce & $C=\exp \left(\frac{-2 \times N D V I}{1-N D V I}\right)$ & Knijff a kol., 1999 \\
\hline Kondenzační funkce & $\begin{array}{c}W B=N D V I+W E T \\
W E T=0.1509 \times B 2+0.1973 \times B 3+0.3279 \times B 4+0.3406 \times \\
B 8-0.7112 \times B 11-0.4572 \times B 12 \\
N D V I=\frac{B 8-B 4}{B 8+B 4}\end{array}$ & $\begin{array}{l}\text { Hesslerová } \\
\text { a Pokorný, } 2010\end{array}$ \\
\hline Vodoretenční funkce & $N D M I=\frac{B 8-B 11}{B 8+B 11}$ & Gao, 1996 \\
\hline $\begin{array}{l}\text { Evapotranspirační } \\
\text { funkce }\end{array}$ & 11 vrstev $z$ dat Sentinel-2 (LAI) & $\begin{array}{l}\text { Biophysical } \\
\text { Processor }\end{array}$ \\
\hline $\begin{array}{l}\text { Produkční funkce } \\
\text { (fotosyntéza) }\end{array}$ & 12 vrstev $z$ dat Sentinel-2 (FAPAR) & $\begin{array}{l}\text { Biophysical } \\
\text { Processor }\end{array}$ \\
\hline Regulační funkce & TotalPM $_{10}=0,0064 * 20 * 30 * 24 * 3600 * L A I * 0,5 * 400$ & $\begin{array}{l}\text { Bottalico a kol., } \\
2016\end{array}$ \\
\hline
\end{tabular}




\section{ZÁVÉR}

Data Sentinel-2 mají vysoký potenciál ke kvantifikaci ekosystémových funkcí. Slabinou je absence snímání v termálním pásmu, kde alternativou je použití Sentinel-3, Landsat 7 nebo Landsat 8 . V souvislosti s výpočtem solární disipace není vhodné použít zmíněné alternativy ze dvou důvodů. Prvním důvodem je horší rozlišení oproti datům Sentinel-2. Tím druhým je odlišná doba snímání povrchu a není vhodné počítat vlhkost vegetace a teplotu povrchu ze dvou jiných dnů, jelikož může hrát roli počasí a výsledek by pak byl nepřesný. Data Sentinel-1 jsou vhodná k použití pro výpočet vlhkosti půdy, nicméně kvůli šumu musí být vzorkována na malé rozlišení $(1 \times 1 \mathrm{~km})$ a nelze je tedy použít $v$ kontextu dané práce. Pro určení biomasy nebyla potvrzena vhodnost dat Sentinel-1.

Při porovnání expertních hodnot $s$ hodnotami získanými $z$ dat DPZ je nutné brát $v$ úvahu pár souvislostí. Expertní určení hodnot uhlíku $v$ biotopech probíhalo $v$ rámci let od roku 2010, kde byla brána průměrná hodnota. Aktuální hodnota získaná z dat DPZ je odlišná, kde může hrát roli více činitelů, jako vývoj vegetace nebo kưrovcová kalamita v zájmovém území. Dalším faktorem může být rozlišení dat. Při rozlišení 20 metrů nelze vhodně zobrazit heterogenitu $v$ daném pixelu. Expertní hodnoty jsou získávány přesně $z$ daného biotopu tzv. reprezentativními vzorky. Při rozlišení dat DPZ tak může docházet k průměrování hodnot, kdy pixel bude $z$ poloviny tvořen travním porostem a $z$ druhé poloviny lesním porostem.

Po testování byly $\mathrm{k}$ jednotlivým indexům príǐazeny ekosystémové funkce. Některé funkce však nelze pouze z družicových dat určit úplně, a tak jsou nahrazeny bezrozměrnou jednotkou, kterou může být vegetační, či vlhkostní index. Co se týče vybraných bezrozměrných jednotek, jedná se o velmi důležité kvantifikátory kvality životního prostředí (FAPAR, LAI, NDMI, C-faktor, sluneční disipace). Určení biomasy je s použitým algoritmem vhodné pouze pro lesní porosty.

\section{LITERATURA}

Askar, Narissara Nuthammachot, Worradorn Phairuang, Pramaditya Wicaksono, and Tri Sayektiningsih. 2018. "Estimating Aboveground Biomass on Private Forest Using Sentinel-2 Imagery." Journal of Sensors 2018. https://doi.org/10.1155/2018/6745629.

Bottalico, Francesca, Gherardo Chirici, Francesca Giannetti, Alessandra De Marco, Susanna Nocentini, Elena Paoletti, Fabio Salbitano, Giovanni Sanesi, Chiara Serenelli, and Davide Travaglini. 2016. "Air Pollution Removal by Green Infrastructures and Urban Forests in the City of Florence." Agriculture and Agricultural Science Procedia 8 (January): 243-51. https://doi.org/10.1016/j.aaspro.2016.02.099.

Copernicus. 2019. "Fraction of Absorbed Photosynthetically Active Radiation | Copernicus Global Land Service.". https://land.copernicus.eu/global/products/fapar.

ČHMÚ. 2018. “Portál ČHMÚ.”. https://www.chmi.cz/.

De Groot, Rudolf S, Matthew A Wilson, and Roelof M J Boumans. 2002. "A Typology for the Classification, Description and Valuation of Ecosystem Functions, Goods and Services." Ecological Economics. Vol. 41. www.elsevier.com/locate/ecolecon.

Dragicevic, Slavoljub, Stanimir Kostadinov, Nada Dragovic, and Radislav Tosic. 2011. "Assessment of Soil Erosion Potential by the USLE Method: Case Study, Republic of Srpska-BiH." https://www.researchgate.net/publication/235986141.

Gao, Bo Cai. 1996. "NDWI - A Normalized Difference Water Index for Remote Sensing of Vegetation Liquid Water from Space." Remote Sensing of Environment 58 (3): 257-66. https://doi.org/10.1016/S00344257(96)00067-3. 
Goodenough, David G, Hao Chen, Andrew Dyk, Tian Han, and Jingyang Li. 2005. "Multisensor Data Fusion For Aboveground Carbon Estimation.” https://www.researchgate.net/publication/228338816.

Hesslerova, Petra, and Jan Pokorný. 2010. "The Synergy of Solar Radiation, Plant Biomass and Humidity as an Indicator of Ecological Functions of the Landscape: A Case Study from Central Europe." Integrated Environmental Assessment and Management preprint (2009): 1. https://doi.org/10.1897/IEAM_2009-058.1.

Knijff, J M Van Der, R J A Jones, and L Montanarella. 1999. "Soil Erosion Risk Assessment Italy."

Liang, Shunlin, Xiaowen Li, and Jindi Wang. 2012. Advanced Remote Sensing. Advanced Remote Sensing. Elsevier Inc. https://doi.org/10.1016/C2010-0-67304-4.

Macedo, Fabrício L., Adélia M. O. Sousa, Ana Cristina Gonçalves, José R. Marques da Silva, Paulo A. Mesquita, and Ricardo A. F. Rodrigues. 2018. "Above-Ground Biomass Estimation for Quercus Rotundifolia Using Vegetation Indices Derived from High Spatial Resolution Satellite Images." European Journal of Remote Sensing 51 (1): 932-44. https://doi.org/10.1080/22797254.2018.1521250.

Pettorelli, Nathalie, Henrike Schulte to Bühne, Ayesha Tulloch, Grégoire Dubois, Cate Macinnis-Ng, Ana M. Queirós, David A. Keith, et al. 2018. "Satellite Remote Sensing of Ecosystem Functions: Opportunities, Challenges and Way Forward." Edited by Marcus Rowcliffe and Mat Disney. Remote Sensing in Ecology and Conservation 4 (2): 71-93. https://doi.org/10.1002/rse2.59.

ÚHUL. 2018. "Národní Inventarizace Lesů.". http://www.uhul.cz/nase-cinnost/narodni-inventarizace-lesu.

Vyvlečka, Pavel. 2020. "Stanovení Vybraných Ekosystémových Funkcí z Dat Družice Sentinel." Olomouc: Katedra Geoinformatiky UPOL.

Zheng, Daolan, John Rademacher, Jiquan Chen, Thomas Crow, Mary Bresee, James Le Moine, and Soung Ryoul Ryu. 2004. "Estimating Aboveground Biomass Using Landsat 7 ETM+ Data across a Managed Landscape in Northern Wisconsin, USA." Remote Sensing of Environment 93 (3): 402-11. https://doi.org/10.1016/j.rse.2004.08.008. 